\title{
Meningkatkan Nilai Matematika Dengan Penerapan Metode Drill Pada Materi Keliling Dan Luas Segitiga Bagi Siswa Kelas Vii Smp Negeri 24 Kabupaten Sorong Tahun 2016
}

\author{
Muhammad Najib \\ SMP Negeri 24 Kabupaten Sorong \\ Email: muhamadnajib@gmail.com
}

\begin{abstract}
The purpose of this class research action is to improving the value of mathematic subject through applying or the drill method with the subject of the research is all of the students grade 7 that the amount is 12 students and consist of 5 male students and 7 female students. This research do in two cycle, which is each cycle is do in four times of meeting. The collecting data do by using Observation and the last cycle test. The data which is collected is analyzed by using qualitative and quantitative analyzis. The result of learning mathematics increase after doing learning proceess by using drill method for about two cycle with the result as follow:(1) beforr learning with drill method applied, the students value is in the low category with the average of the value 47,75 from the high result 50 and the low result is 42. (2) after learning by using drill method in the first cycle the stufents value is in the middle category with the average of the result is 55,88 from the high result 60 and the low result 44. (3) after learning proceess by using drill method in the second cycle, the students value is in the high category which the average value or score is 68,50 from the hugh score is 78 and the low score is 55.
\end{abstract}

Keyword : the result of learning mathematics, learning proceess by using drill method

\begin{abstract}
Abstrak: Tujuan Penelitian Tindakan Kelas ini adalah untuk meningkatkan nilai matematika melalui penerapan pembelajaran metode drill dengan subyek penelitian adalah seluruh siswa kelas VII dengan siswa sebanyak 12 orang, terdiri dari 5 orang laki-laki dan 7 orang perempuan. Penelitian ini dilakukan dalam 2 siklus, yang masing-masing dilaksanakan selama empat kali pertemuan. Pengambilan data dilakukan dengan menggunakan Observasi dan Tes Akhir Siklus. Data yang terkumpul dianalisis dengan menggunakan analisis kualitatif dan kuantitatif. Hasil belajar matematika meningkat setelah dilakukan pembelajaran dengan metode drill selama dua siklus dengan hasil sebagai berikut: (1) Sebelum pembelajaran dengan metode drill diterapkan berada dalam kategori rendah dengan nilai rata-rata 47,75 dari nilai tertinggi 50 dan nilai terendah 42. (2) Setelah pembelajaran dengan metode drill diterapkan pada Siklus I berada dalam kategori sedang dengan nilai rata-rata 55,88 dari nilai tertinggi 60 dan nilai terendah 44. (3). Setelah pembelajaran dengan metode drill dilaksanakan pada Siklus II berada dalam kategori tinggi dengan nilai rata-rata 68,50 dari nilai tertinggi 78 dan nilai terendah 55 .
\end{abstract}

Kata kunci : Nilai belajar Matematika, pembelajaran metode drill

\section{Pendahuluan}

Matematika adalah konsep ilmu tentang logika mengenai bentuk, susunan, besaran, dan konsep-konsep yang berhubungan satu dengan yang lainnya dengan jumlah yang banyak, yang terbagi ke dalam tiga bidang yaitu: aljabar, analisis, dan geometri. Dalam kenyataannya selain tiga bidang ilmu yang tersebut, kita mengenal sub atau cabang ilmu yang masih termasuk dalam matematika, diantaranya adalah: aritmatika, trigonometri, kalkulus, statistik 
dan lain-lain. Pada penelitian ini, peneliti memilih topik tentang keliling dan luas bangun datar, khususnya tentang keliling dan luas segitiga. Kenyataannya masih banyak siswa yang sulit untuk mempelajarinya, biasanya kesulitannya terletak pada kurangnya keterampilan siswa dalam mengolah dan menerapkan rumus yang sebenarnya telah mereka ketahui. Matematika tidak dapat dipelajari hanya dengan cara menghafal saja, namun belajar matematika memerlukan keterampilan dalam menerapkan rumus-rumus dan pembuktian teorema-teorema. Jadi pada saat belajar matematika siswa harus banyak latihan mengerjakan soal-soal yang ada agar keterampilan matematika siswa dapat meningkat.

Untuk dapat melaksanakan pembelajaran dengan menerapkan atau memberi keterangan-keterangan diperlukan suatu metode drill yaitu suatu cara mengajar yang mana siswa melaksanakan kegiatan-kegiatan dengan mengerjakan latihan-latihan, sehingga dapat memecahkan masalah pada pelajaran matematika, agar siswa memiliki ketangkasan dan keterampilan, kemampuan yang lebih tinggi dari yang dipelajari. Untuk meningkatkan prestasi belajar matematika siswa dengan metode drill tersebut, perlu adanya kerja sama antara guru matematika dengan peneliti yaitu melalui penelitian tindakan kelas (PTK). Proses PTK ini memberikan kesempatan kepada peneliti dan guru matematika untuk mengidentifikasi masalah-masalah pembelajaran di sekolah sehingga dapat dikaji, ditingkatkan dan dituntaskan.

Dalam proses pembelajaran matematika pasti akan ada suatu waktu di mana guru memberikan latihan kepada siswa, terutama pada saat guru selesai menyampaikan materi tertentu. Kebanyakan siswa menganggap bahwa pemberian latihan adalah untuk mendapatkan nilai saja, padahal pemberian latihan bukan hanya untuk mendapatkan nilai saja tetapi juga untuk menciptakan dan meningkatkan keterampilan siswa dalam menyelesaikan permasalahan dalam matematika.

Dengan demikian, prestasi belajar matematika dapat meningkat tidak hanya dilakukan mendengarkan guru menerangkan di depan kelas saja, akan tetapi diperlukan banyak latihanlatihan. Proses pembelajaran matematika di sekolah yang menerapkan metode drill diharapkan dapat meningkatkan prestasi belajar matematika siswa ditinjau dari minat belajar terutama dalam menentukan keliling dan luas segitiga. Oleh karena itu, penulis menganggap bahwa metode drill ini tepat diterapkan untuk meningkatkan keterampilan siswa kelas VII SMP Negeri 24 Kabupaten Sorong.

Sesuai dengan permasalahan, tujuan dan teori yang dikemukakan maka hipotesis dalam penelitian ini adalah penerapan metode drill dapat meningkatkan keterampilan matematika pada materi keliling dan luas segitiga siswa kelas VII SMP Negeri 24 Kabupaten Sorong. 


\section{Metode Penelitian}

\subsection{Desain Penelitian}

Penelitian ini merupakan penelitian Penelitian Tindakan Kelas (Classroom Action Research), dengan tahapan-tahapan pelaksanaan yang meliputi : perencanaan, pelaksanaan, tindakan, refleksi, dan evaluasi secara berulang. Penelitian Tindakan Kelas ini terdiri dari 2 (dua) siklus. Siklus I (pertama) dilaksanakan selama empat kali pertemuan dan Siklus II ( kedua ) juga dilaksanakan selama empat kali pertemuan. Penelitian ini mengikuti prosedur "spiral" yang digambarkan dalam diagram berikut :

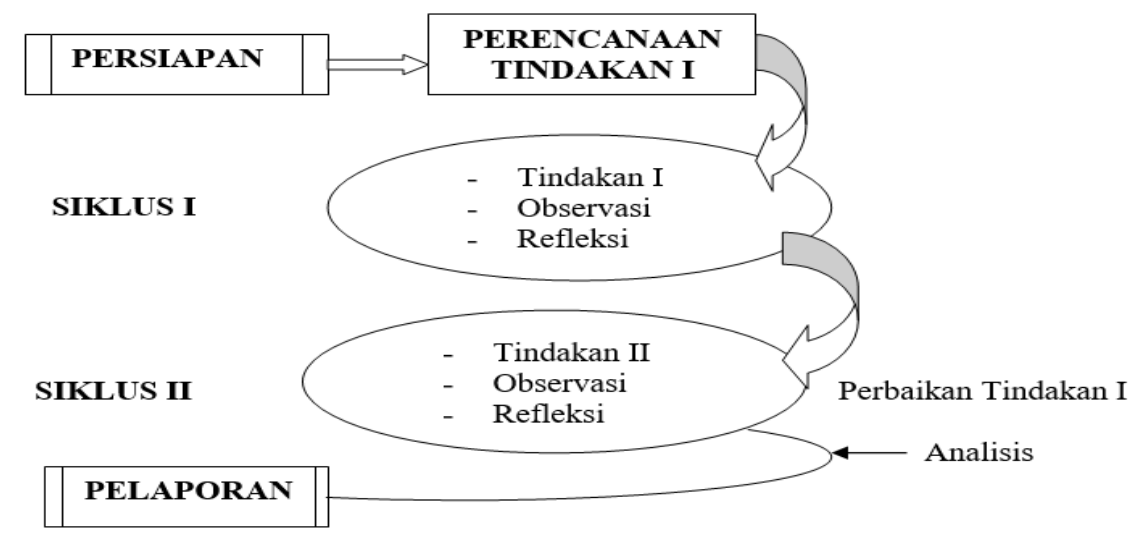

Gambar 1. Siklus Penelitian

\subsection{Subjek Penelitian}

Subjek penelitian dalam penelitian ini adalah siswa kelas VII dengan jumlah siswa 12 orang yang terdiri dari 5 siswa laki-laki dan 7 siswa perempuan yang dilaksanakan pada semester II Tahun Pelajaran 2015/2016.

\subsection{Teknik Pengumpulan Data}

Dalam pengumpulan data yang dilakukan pada penelitian ini adalah :

- Data mengenai peningkatan hasil belajar diambil dari tes setiap siklus, yang mana tes setiap siklus ini dibuat oleh penulis, sebagai guru mata pelajaran.

- Data tentang situasi belajar mengajar pada saat dilakukan tindakan diambil dengan menggunakan lembar observasi.

- Data tentang pelaksanaan tindakan diperoleh dari hasil angket dan memberikan kesempatan kepada siswa untuk menuliskan tanggapan pada akhir siklus.

\subsection{Teknik Analisis Data}


Data yang sudah terkumpul dianalisis secara kuantitatif dan kualitatif. Untuk analisis cara kuantitatif digunakan analisis deskriptif, yaitu nilai rata-rata dan persentase. Selain itu pula akan ditentukan nilai minimum dan maksimum yang diperoleh siswa pada setiap bahasan. Kemudian nilai tersebut dikategorikan dengan menggunakan Kategorisasi Skala Lima berdasarkan teknik kategorisasi dari Departemen Pendidikan Nasional yang dinyatakan sebagai berikut :

Tabel 1. Kategori Skala Lima

\begin{tabular}{ccc}
\hline NO. & N I L A I & K A T E G O R I \\
\hline 1. & $0-34$ & Sangat Rendah \\
2. & $35-54$ & Rendah \\
3. & $55-64$ & Sedang \\
4. & $65-84$ & Tinggi \\
5. & $85-100$ & Sangat Tinggi \\
\hline
\end{tabular}

Sedangkan analisis kualitatif dilaksanakan sesuai dengan kecenderungan yang terjadi pada setiap siklus dengan melakukan penilaian secara verbal (aktivitas yang teramati). Untuk menentukan daya serap siswa terhadap materi yang diajarkan pada saat pemberian tindakan yang didasarkan pada perolehan nilai hasil belajar matematika setiap siswa pada setiap siklus, daya serap siswa tersebut diperoleh dengan menggunakan rumus sebagai berikut :

Daya serap siswa $=\frac{\text { skor perolehan siswa }}{\text { skor maksimum (100) }} \times 100 \%$

Sedangkan untuk menentukan ketuntasan belajar siswa, dipergunakan Nilai Kriteria Ketuntasan Minimal ( KKM ) mata pelajaran Matematika pada SMP Negeri 24 Kabupaten Sorong, sebesar $60 \%$. Adapun kategorisasai ketuntasan belajar siswa terdiri dari kriteria tuntas dan tidak tuntas, yaitu:

Tabel 2. Kategori Ketuntasan Belajar

\begin{tabular}{cc}
\hline Ketuntasan Belajar Siswa & Kategori Ketuntasan Balajar \\
\hline $0 \%-59,99 \%$ & Tidak Tuntas \\
$60 \%-100,00 \%$ & T u n t a s \\
\hline
\end{tabular}

Indikator keberhasilan dalam penelitian ini adalah meningkatnya kehadiran dan motivasi dalam belajar matematika serta nilai rata-rata hasil belajar mengalami peningkatan.

\section{Hasil dan Pembahasan}

Berdasarkan hasil observasi dari pelaksanaan penelitian tindakan ini diperoleh kemampuan awal siswa Kelas VII SMP Negeri 24 Kabupaten Sorong, yang diambil dari nilai 
ulangan harian materi sebelumnya, didapat data pre-test (sebelum diterapkan metode drill) ini diperoleh dari pemberian tes yang terdiri dari 5 butir soal, dimana pada tiap-tiap butir soal terdapat tiga komponen keterampilan yang ingin diteliti, yaitu: (a) keterampilan menggambar segitiga, (b) keterampilan menuliskan rumus keliling dan luas segitiga, dan (c) keterampilan menyelesaikan masalah yang berhubungan dengan keliling dan luas segitiga. Hasil tes yang diperoleh sebelum penerapan metode drill adalah skor tertinggi 50 dan skor terendah 42 sehingga rata-rata nilai sebelum diterapkan metode drill adalah 47,75 . Hal itu dapat dilihat pada tabel berikut ini :

Tabel 3. Statistik Nilai Kemampuan Awal Siswa Kelas VII

\begin{tabular}{cc}
\hline Statistik & Nilai Statistik \\
\hline Subyek & 12 \\
Nilai Ideal & 100,00 \\
Nilai Tertinggi & 50 \\
Nilai Terendah & 42 \\
Rentang Nilai & 8 \\
Nilai rata-rata & 47,75 \\
\hline
\end{tabular}

Dari data tersebut di atas, jika nilai hasil belajar matematika dikelompokkan ke dalam lima kategori, maka dapat dikatakan sebelum dilakukan pembelajaran dengan metode drill berada pada kategori "rendah".

Pembelajaran matematika siswa setelah dilakukan pembelajaran dengan metode drill pada akhir siklus I diperoleh nilai hasil belajar matematika yang berbentuk ulangan harian setelah selesai penyajian satu pokok bahasan, dapat dilihat pada tabel 4 . berikut ini :

Tabel 4. Statistik nilai hasil belajar matematika siswa, pada tes akhir Siklus I

\begin{tabular}{cc}
\hline Statistik & Nilai Statistik \\
\hline Subyek & 12 \\
Nilai Ideal & 100 \\
Nilai Tertinggi & 60 \\
Nilai Terendah & 44 \\
Rentang Nilai & 14 \\
Nilai Rata-Rata & 55,08 \\
\hline
\end{tabular}


Apabila nilai hasil belajar matematika siswa dikelompokkan ke dalam lima kategori, maka disimpulkan bahwa hasil belajar siswa setelah dilakukan pembelajaran dengan metode drill pada Siklus I berada pada kategori "sedang".

Pada pembelajaran Matematika Siswa pada Akhir Siklus II setelah diterapkan pembelajaran dengan metode drill dapat dilihat pada tabel 5. berikut ini :

Tabel 5. Statistik Nilai Hasil Belajar Matematika Siswa setelah Tes Akhir Siklus II

\begin{tabular}{cc}
\hline Statistik & Nilai Statistik \\
\hline Subyek & 12 \\
Nilai Ideal & 100 \\
Nilai Tertinggi & 78 \\
Nilai Terendah & 55 \\
Rentang Nilai & 23 \\
Nilai Rata-Rata & 68,50 \\
\hline
\end{tabular}

Dari nilai hasil belajar matematika siswa tersebut, maka disimpulkan bahwa hasil belajar matematika siswa Kelas VII SMP Negeri 24 Kabupaten Sorong setelah dilakukan tindakan pembelajaran dengan metode drill pada Siklus II berada pada kategori "tinggi".

\section{Simpulan dan Saran}

\subsection{Kesimpulan}

Keterampilan matematika siswa kelas VII SMP Negeri 24 Kabupaten Sorong materi keliling dan luas segitiga sebelum penerapan metode drill adalah rendah, yaitu berdasarkan nilai rata-rata skor per-test 47,75. Setelah penerapan metode drill siklus I adalah 55,08 atau berada pada kategori sedang, walaupun terjadi peningkatan perolehan rata-rata nilai sebesar 8,05 . Pada penerapan metode drill siklus II diperoleh nilai rata-rata sebesar 68,50 atau berada pada kategori tinggi, terjadi peningkatan perolehan rata-rata nilai sebesar 13,42. Hal ini menunjukkan bahwa terdapat peningkatan pada keterampilan matematika siswa pada materi keliling dan luas segitiga. Artinya penerapan metode drill dapat meningkatkan keterampilan matematika siswa kelas VII SMP Negeri 24 Kabupaten Sorong pada Kompetensi Dasar keliling dan luas segitiga semester II Tahun Pelajaran 2015/2016.

\subsection{Saran}

Berdasarkan hasil penelitian di atas, maka peneliti dapat memberikan saran sebagai berikut : 
1) Hal yang harus diperhatikan apabila akan menerapkan metode drill adalah dalam melakukan pemilihan materi dapat menggunakan pendekatan Contextual Teaching and Learning (CTL) dan menyusun perencanaan pembelajaran perlu mendapat perhatian yang khusus agar dapat menghasilkan rencana pembelajaran yang baik.

2) Banyak melakukan kolaborasi, semakin banyak guru yang diajak berkolaborasi akan dapat meringankan pekerjaan guru.

\section{Daftar Pustaka}

Arikunto, Suharsimi. 2013. Prosedur Penelitian Suatu Pendekatan Praktek. Jakarta: Rineka Cipta.

2010. Dasar-Dasar Evaluasi Pendidikan. Jakarta: Bumi Aksara.

Asmani, Jamal Ma'mur. 2009. 7 Tips Aplikasi PAKEM. Jogjakarta: DIVA Press.

Djamarah, Syaiful Bahri dan Aswan Zain. 2009. Strategi Belajar Mengajar. Jakarta: Rineka Cipta.

Hamdani, M.A. 2009. Strategi Belajar Mengajar. Bandung: CV. Pustaka Setia.

Kardi, Soeparaman dan Mohamad Nur. 2000. Pengantar Pada Pengajaran dan Pengelolaan Kelas. Surabaya: UNESA-University Press.

Tea,Tautik. 2009. Inspiring Teaching. Jakarta: Gema Insani.

Sagala, Syaiful. 2009. Konsep dan Makna Pembelajaran. Bandung: CV. Alfabeta.

Sudjana, Nana. 1995. Dasar-Dasar Proses Belajar Mengajar. Bandung: Sinar Baru Algensindo. 